\title{
ANALYSIS OF ANTIGEN CONSERVATION AND INACTIVATION OF GAMMA-IRRADIATED AVIAN INFLUENZA VIRUS SUBTYPE H9N2
}

\author{
BAHAREH SALEhI ${ }^{1}$, FARAHNAZ MOtAMEdi-SEDEH ${ }^{2} *$ OMID MADAdGAR $^{1}$, \\ IRAJ KHALILI ${ }^{3}$, ARASH GHALYAN CHI LANGROUdi ${ }^{1}$, HERMANN UNGER ${ }^{4}$ and \\ VISKAM WIJEWARDANA ${ }^{4}$ \\ ${ }^{1}$ Faculty of Veterinary Medicine, University of Tehran, Tehran, Iran \\ ${ }^{2}$ Nuclear Agriculture Research School, Nuclear Science and \\ Technology Research Institute, Tehran, Iran \\ ${ }^{3}$ Quality Control Department, Razi Vaccine and Serum Research Institute, Karaj, Iran \\ ${ }^{4}$ Department of Nuclear Sciences and Applications, Animal Production and Health \\ Section, International Atomic Energy Agency (IAEA), VIC, Vienna, Austria
}

(Received: 2 October 2017; accepted: 7 March 2018)

\begin{abstract}
Avian influenza (AI) A subtype H9N2 virus belongs to Orthomyxoviridae family and causes low-pathogenic disease AI. The use of gamma-irradiated viral antigens has been developed in the production of effective vaccines. In this research, LPAIV H9N2 strain, A/Chicken/IRN/Ghazvin/2001, was multiplied on SPF eggs and irradiated by a Nordian gamma cell instrument. Irradiated and non-irradiated AI virus (AIV) samples were titrated by EID50 method and hemagglutinin (HA) antigen was analyzed by HA test as the WHO pattern method. Infectivity of irradiated virus was determined by egg inoculation method during four blind cultures. The results showed that after increasing the dose of gamma radiation, virus titer gradually decreased. $D_{10}$ value and optimum dose for complete virus inactivation were calculated by dose/response curve, 3.36 and $29.52 \mathrm{kGy}$, respectively. In addition, HA antigenicity of gamma-irradiated virus samples from 0 to $30 \mathrm{kGy}$ was not changed. The results of safety test for gammairradiated AIV samples showed complete inactivation with gamma ray doses 30 and $35 \mathrm{kGy}$, without any multiplication on eggs after four blind cultures. According to the results of HA antigen assay and safety test, the gamma-irradiated and complete inactivated AIV subtype H9N2 is a good candidate as an inactivated immunogenic agent for poultry vaccination.
\end{abstract}

Keywords: avian influenza A subtype H9N2 virus, gamma irradiation, hemagglutinin antigen, inactivation

*Corresponding author; E-mail: farah.motamedi@gmail.com 


\section{Introduction}

Avian influenza (AI) is caused by specified viruses that are members of the family Orthomyxoviridae and placed in the genus Influenza virus A. There are three influenza genera - A, B, and C; only Influenza A viruses are known to infect birds [1].

Influenza viruses type A are classified into different subtypes, based on two surface glycoproteins [hemagglutinin (HA) and neuraminidase] [2]. AI A subtype H9N2 virus is circulating in domestic poultry worldwide. Although this subtype is generally not highly pathogenic for avian species, this virus has recently been transmitted to mammalian species, including humans [3]. Influenza viruses type A are divided into two groups according to the virulence for chickens. Highly pathogenic AI (HPAI) viruses cause rapid mortality up to $100 \%$, whereas non-HPAI viruses including mildly pathogenic, low-pathogenic AI virus (AIV) (LPAIV), and non-pathogenic AIV may cause mild respiratory disease with low mortality or may not cause disease [4]. The HPAI viruses have been obtained from $\mathrm{H} 5$ or H7 subtypes [5]. Influenza A viruses of subtypes H9N2 and H5N1 are low pathogenic and highly pathogenic AIV, respectively, and considered as zoonotic subtypes.

The use of gamma-irradiated viral antigens has been developed in the production of effective vaccines as well as for diagnostic purposes. The dose of gamma radiation for viral inactivation is related to the virus concentration, the size of the particles containing viral genomes, and the temperature of irradiation. The aim of this study is using gamma irradiation to inactivate AI virus A subtype H9N2 without any change in HA antigen characteristics as an immunogenic to induce immune responses.

\section{Materials and Methods}

\section{Virus multiplication}

The isolated virus that is used in this study was LPAIV H9N2 strain, A/Chicken/IRN/Ghazvin/2001. The viral suspension $(0.2 \mathrm{ml})$ was inoculated into the allantoic sac of embryonated SPF chicken eggs of 9-11 days incubation. The eggs are incubated at $37^{\circ} \mathrm{C}$ (range: $35-39^{\circ} \mathrm{C}$ ) for $2-5$ days. All the eggs remaining at the end of the incubation period were chilled to $4{ }^{\circ} \mathrm{C}$ for $4 \mathrm{~h}$ or overnight, and the allantoic fluids were harvested $96 \mathrm{~h}$ after inoculation and centrifuged at 1,500 $\times \mathrm{g}$ at $4{ }^{\circ} \mathrm{C}$ for $10 \mathrm{~min}$ to separate $\mathrm{RBC}$ and other cells. The allantoic fluids were tested using hemagglutination test, each negative sample was tested again and each positive sample was stored in $-70{ }^{\circ} \mathrm{C}$ [1]. 
The infectious viral titer was determined using 10-day-old embryonated SPF eggs and egg infectious dose 50 (EID50) was calculated according to Reed and Muench [6] and OIE manual.

\section{Gamma irradiation and inactivation of virus samples}

Gamma radiation was used for the inactivation of AI A subtype H9N2 viruses. AIV was irradiated by a Nordian model 220 gamma cell instrument at a dose rate of $2.07 \mathrm{~Gy} / \mathrm{s}$ and activity of $8677 \mathrm{Ci}$ to cripple influenza virus genomic RNA and to inactivate virus infectivity. Gamma ray doses of 5, 10, 15, 20, 25, and $30 \mathrm{kGy}$ were administered for the frozen virus samples and three sample replicates were irradiated for each dose. The titers of irradiated AIV samples were first obtained by EID50 method, and then a dose/response curve was drawn using Origin software. The $\mathrm{D}_{10}$ value (dose of gamma radiation, which can decrease one logarithmic cycle of virus population) and optimum dose of gamma rays for AIV inactivation were determined according to the dose/response curve. Finally, $50 \mathrm{ml}$ of the AIV was irradiated by the optimized dose of gamma ray and used for safety test to confirm complete virus inactivation.

\section{Virus titration of irradiated and non-irradiated samples}

Virus titers were determined in embryonated SPF chicken EID50/ml by endpoint dilution and the calculation method of Reed and Muench [6]. The EID50 is a biological method to determine the amount of infectious virus in a sample by determining the highest dilution of the sample that can infect $50 \%$ of the embryonated chicken eggs. This assay entailed performing the serial dilutions of the viral sample and $0.1 \mathrm{ml}$ of each dilution was inoculated for each egg. To determine the best dilution to produce a $50 \%$ positive result, the Reed-Muench [6] method is used. This method requires the use of three or more eggs per dilution to determine the 50\% endpoint by performing a hemagglutination assay for each inoculated egg.

\section{HA antigen assay}

HA antigen of irradiated and non-irradiated viral samples was analyzed using hemagglutination test as the WHO pattern method. An amount of $50 \mu \mathrm{l}$ of phosphate-buffered saline (PBS) was added to wells 2-12, and $100 \mu \mathrm{l}$ of each tested virus to the first well. Twofold serial dilutions were made by transferring $50 \mu \mathrm{l}$ from the first well to successive well-11 and discarded the final $50 \mu \mathrm{l}$ from well-11. Well-12 contained only PBS as RBC control. An amount of $50 \mu \mathrm{l}$ of 
$0.5 \%$ RBC suspension was added to each well on the plate. Then, the plates were mixed and incubated at room temperature for $30 \mathrm{~min}$. The titers of viruses were recorded after 30 min by tipping plates and reading $\mathrm{RBC}$ buttons that stream. The highest dilution of virus that causes complete hemagglutination is considered to be the HA titration end point. The HA titer is the reciprocal of the dilution of virus in the last well with complete hemagglutination [7].

\section{Safety test}

Infectivity of irradiated virus samples (by different doses of gamma ray: 25, 30 , and $35 \mathrm{kGy}$ ) was determined by eggs inoculation method during four blind cultures on eggs. All of the irradiated virus samples were inoculated on embryonated SPF chicken eggs of 9-11 days; also their titration was obtained by EID50 methods.

\section{Results}

The results of virus titration by EID50 method for non-irradiated AIV sample were calculated and shown in Table I. It was $10^{8.77} \mathrm{ml}^{-1}$ and the virus titration for irradiated virus samples was calculated (Table II). According to the increasing dose of gamma radiation, virus titration decreased gradually.

Proportionate distance $(\mathrm{Pd})=\{(\%$ positive above $50 \%)-50 \%\} /$

$\{(\%$ positive above $50 \%)-(\%$ positive below $50 \%)\}$,

$$
\operatorname{Pd}=(77-50) /(77-42)=0.77 \text {. }
$$

$(\log$ dilution above 50\% $)+(\mathrm{Pd} \times \log$ dilution factor $)=\log$ ID 50,

$$
\begin{aligned}
-7+[0.77 \times(-1)] & =-7.77 \\
& \text { EID50 }=10^{7.77} / 0.1 \mathrm{ml}, \\
& \text { EID50 }=10^{8.77} / \mathrm{ml} .
\end{aligned}
$$

Table I. Titration of non-irradiated avian influenza A subtype H9N2 virus by Reed and Muench method (EID50/ml)

\begin{tabular}{lcccccc}
\hline Dilution & Positive & Negative & $\begin{array}{c}\text { Cumulative no. } \\
\text { positive (A) }\end{array}$ & $\begin{array}{c}\text { Cumulative no. } \\
\text { negative (B) }\end{array}$ & A/(A+B) & $\begin{array}{c}\text { Percentage } \\
(\%)\end{array}$ \\
\hline $10^{-6}$ & 4 & 1 & 11 & 1 & $11 / 12$ & 91 \\
$10^{-7}$ & 4 & 1 & 7 & 2 & $7 / 9$ & 77 \\
$10^{-8}$ & 3 & 2 & 3 & 4 & $3 / 7$ & 42 \\
\hline
\end{tabular}


Table II. Titration of gamma-irradiated avian influenza A subtype H9N2 virus samples

\begin{tabular}{lccccc}
\hline Dose of gamma radiation (kGy) & 0 & 5 & 10 & 15 & 20 \\
\hline Virus titration (EID50/ml) & $10^{8.77}$ & $10^{5.47}$ & $10^{4.83}$ & $10^{4.17}$ & $10^{2.33}$ \\
\hline
\end{tabular}

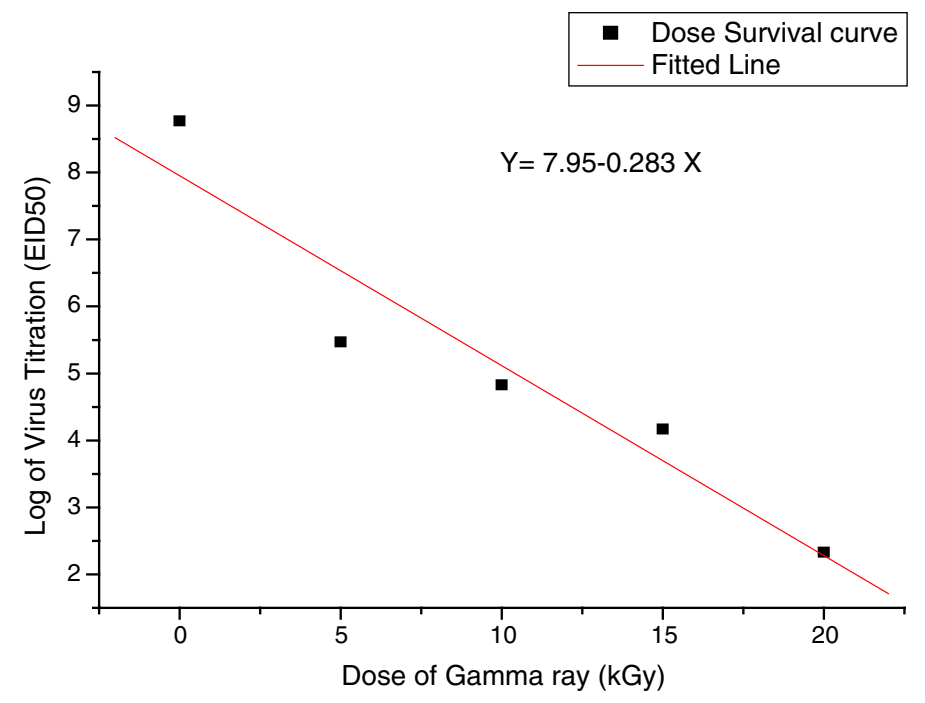

Figure 1. Dose-response curve for irradiated avian influenza A subtype H9N2 virus

$\mathrm{D}_{10}$ value and optimum dose for complete virus inactivation were calculated by dose/response curve (Figure 1), 3.36 and $29.52 \mathrm{kGy}$, respectively.

HA antigen assay was carried out and the results showed that the HA antigenicity of gamma-irradiated virus samples from 0 to $30 \mathrm{kGy}$ was not changed (Table III).

The results of safety test for gamma-irradiated AIV subtype H9N2 samples showed complete inactivation with gamma ray doses 30 and $35 \mathrm{kGy}$, without any multiplication on eggs after four blind cultures (Table IV). According to the results of HA antigen assay and safety test, the gamma-irradiated and complete inactivated AIV subtype H9N2 is a good candidate as an inactivated immunogenic agent for poultry vaccination.

\section{Discussion}

Nowadays, a wide range of novel methods have been described to inactivate viruses, such as ethylenimine derivatives [8], hydrogen peroxide [9], 
Table III. The results of hemagglutinin antigen assay for irradiated and non-irradiated avian influenza A subtype H9N2 virus samples

\begin{tabular}{|c|c|c|c|c|c|c|c|c|c|c|c|}
\hline \multirow{2}{*}{$\begin{array}{l}\text { Dose of } \\
\text { gamma } \\
\text { radiation } \\
(\mathrm{kGy})\end{array}$} & \multicolumn{11}{|c|}{ Virus dilution } \\
\hline & $1 / 2$ & $1 / 4$ & $1 / 8$ & $1 / 16$ & $1 / 32$ & $1 / 64$ & $1 / 128$ & $1 / 256$ & $1 / 512$ & $1 / 1024$ & $\begin{array}{c}\text { Negative } \\
\text { control }\end{array}$ \\
\hline 0 & + & + & + & + & + & + & + & + & - & - & - \\
\hline 2 & + & + & + & + & + & + & + & + & - & - & - \\
\hline 5 & + & + & + & + & + & + & + & + & + & - & - \\
\hline 10 & + & + & + & + & + & + & + & + & - & - & - \\
\hline 15 & + & + & + & + & + & + & + & + & - & - & - \\
\hline 20 & + & + & + & + & + & + & + & + & - & - & - \\
\hline 30 & + & + & + & + & + & + & + & + & - & - & - \\
\hline
\end{tabular}

Table IV. The results of safety test for gamma-irradiated avian influenza A subtype H9N2 virus

\begin{tabular}{lllll}
\hline \multirow{2}{*}{$\begin{array}{l}\text { Dose of gamma } \\
\text { radiation (kGy) }\end{array}$} & First passage & Second passage & Third passage & Fourth passage \\
\cline { 2 - 5 } & Positive & Positive & Positive & Positive \\
30 & Negative & Negative & Negative & Negative \\
35 & Negative & Negative & Negative & Negative \\
\hline
\end{tabular}

gamma irradiation [10, 11] and UV treatment [12], heat [13], etc. [14]. Nonetheless, only formaldehyde and $\beta$-propiolactone are widely used for inactivation of viral vaccines for decades. Formaldehyde is the most widely used inactivating agent for vaccine purposes and many pathogens have been subjected to the irreversible modifications by cross-linking of various amino acids. In addition, the effects of formaldehyde are a great diversity of modifications (methyl groups, Schiff bases, and methylene bridges) and other mechanisms are subject of investigation in several recent studies [15-18]. But safety of formaldehyde is very complicated. It is not acutely toxic as ingestion of many milliliters is tolerated. WHO International Agency for Research on Cancer (IARC) in 1995 also classified formaldehyde as a probable human carcinogen. Further information and evaluation of all known data led the IARC to reclassify formaldehyde as a known human carcinogen, associated with nasal sinus cancer and nasopharyngeal cancer $[19,20]$. Recent studies have also shown a positive correlation between exposure to formaldehyde and the development of leukemia, particularly myeloid leukemia [20]. In addition, formaldehyde can cause allergies [20]. 
In July 1998, H9N2 subtype influenza A virus (LPAIV) was reported in the industrial poultry population of Iran [21]. Due to the widespread occurrence of the H9N2 LPAIV, and the zoonotic potential of the virus, vaccination of chicken with water-in-oil emulsion-inactivated vaccine was employed to control the disease in the country [22].

The conventional H9N2 subtype influenza A vaccine was inactivated by formaldehyde, it makes some residue in the vaccine. In this study, gamma irradiation was used to inactivate virus, without any residue and without any change in HA antigen characteristics. Therefore, the irradiated inactivated H9N2 subtype influenza A virus can be used as an immunogenic to induce immune responses.

\section{Acknowledgements}

The authors would like to express their gratitude for the support provided by International Atomic Energy Organization (IAEA), Vienna, Austria and Nuclear Science and Technology Research Institute, Karaj, Iran. They would also like to thank the Ministry of Science, Research and Technology, Research Council of Faculty of Veterinary Medicine of University of Tehran, Iran and Razi Vaccine and Serum Research Institute of Iran.

\section{Conflict of Interest}

The authors declare no conflict of interest regarding the publication of this paper.

\section{References}

1. OIE Terrestrial Manual: Avian influenza. Infection with avian influenza virus. World Organization for Animal Health, Chapter 2.3.4, 2015, p. 1.

2. Anvar, E., Hosseini, S. M., Tavasoti-Khiri, M., Mazaheri, V., Fazaei, K., Shabani, M.: Serological survey of avian influenza (H9N2) among different occupational groups in Tehran and Ghazvin provinces in IR Iran. Jundishapure J Microbiol 6, e5441 (2013).

3. Lu, X., Renshaw, M., Tumpey, T. M., Kelly, G. D., Hu-Primmer, J., Katz, J. M.: Immunity to influenza A H9N2 viruses induced by infection and vaccination. J Virol 75, 4896-4901 (2001).

4. Naeem, K., Ullah, A., Manvell, R. J., Alexander, D. J.: Avian influenza A subtype H9N2 in poultry in Pakistan. Vet Rec 145, 560 (1999).

5. Alexander, D. J.: Phylogenetic analysis of influenza A virus of H9 hemagglutinin subtype. Avian Pathol 29, 353-360 (2000). 
6. Reed, L. J., Muench, H.: A simple method of estimating 50\% endpoints. Am J Hyg 27, 493-497 (1938).

7. WHO: Laboratory Procedures. Serological Detection of Avian Influenza A (H7N9) Virus Infections by Turkey Haemagglutination-Inhibition Assay. WHO Collaborating Center for Reference and Research on Influenza Chinese National Influenza Center, National Institute for Viral Disease Control and Prevention, China CDC, Beijing, 2013. Available at http:// www.who.int/influenza/gisrs_laboratory/cnic_serological_diagnosis_hai_a_h7n9.pdf

8. Larghi, O. P., Nebel, A. E.: Rabies virus inactivation by binary ethylenimine: New method for inactivated vaccine production. J Clin Microbiol 11, 120-122 (1980).

9. Amanna, I. J., Raue, H. P., Slifka, M. K.: Development of a new hydrogen peroxide-based vaccine platform. Nat Med 18, 974-979 (2012).

10. Martin, S. S., Bakken, R. R., Lind, C. M., Garcia, P., Jenkins, E., Glass, P. J., Parker, M. D., Hart, M. K., Fine, D. L.: Comparison of the immunological responses and efficacy of gamma-irradiated V3526 vaccine formulations against subcutaneous and aerosol challenge with Venezuelan equine encephalitis virus subtype IAB. Vaccine 28, 1031-1040 (2010).

11. Alsharifi, M., Mullbacher, A.: The gamma-irradiated influenza vaccine and the prospect of producing safe vaccines in general. Immunol Cell Biol 88, 103-104 (2010).

12. Budowsky, E. I., Bresler, S. E., Friedman, E. A., Zheleznova, N. V.: Principles of selective inactivation of viral genome. I. UV-induced inactivation of influenza virus. Arch Virol 68, 239-247 (1981).

13. Nims, R. W., Plavsic, M.: Polyomavirus inactivation - A review. Biologicals 41, 63-70 (2012).

14. Stauffer, F., El-Bacha, T., Da-Poian, A. T.: Advances in the development of inactivated virus vaccines. Recent Pat Antiinfect Drug Discov 1, 291-296 (2006).

15. Metz, B., Kersten, G. F., Hoogerhout, P., Brugghe, H. F., Timmermans, H. A., De-Jong, A., Meiring, H., Ten-Hove, J., Hennink, W. E., Crommelin, D. J., Jiskoot, W.: Identification of formaldehyde-induced modifications in proteins: Reactions with model peptides. J Biol Chem 279, 6235-6243 (2004).

16. Metz, B., Kersten, G. F., Baart, G. J., De-Jong, A., Meiring, H., Ten-Hove, J., Van-Steenbergen, M. J., Hennink, W. E., Crommelin, D. J., Jiskoot, W.: Identification of formaldehyde-induced modifications in proteins: Reactions with insulin. Bioconjug Chem 17, 815-822 (2006).

17. Thaysen-Andersen, M., Jorgensen, S. B., Wilhelmsen, E. S., Petersen, J. W., Hojrup, P.: Investigation of the detoxification mechanism of formaldehyde-treated tetanus toxin. Vaccine 25, 2213-2227 (2007).

18. Nunnally, B. K., Turula, V. E., Sitrin, R. D.: Vaccine analysis: Strategies, principles, and control. In Sanders, B., Koldijk, M., Schuitemaker, H. (ed): Inactivated Viral Vaccine, Chapter 2. Springer-Verlag, Berlin/Heidelberg, 2015. Available at http://www.springer. com/978-3-662-45023-9

19. International Agency for Research on Cancer: IARC Monographs on the Evaluation of Carcinogenic Risks to Humans: Formaldehyde, 2-Butoxyethanol and 1-tert-Butoxypropan2-ol. International Agency for Research on Cancer, Lyon, 2006, p. 88. Available at http:// monographs.iarc.fr/ENG/Monographs/vol88/index.php

20. National Cancer Institute [NIH]: Formaldehyde and Cancer Risk, 2017. Available at https://www.cancer.gov/about-cancer/causes-prevention/risk/substances/formaldehyde/ formaldehyde-fact-sheet 
21. Vasfi-Marandi, M., Bozorgmehrifard, M. H., Hashemzadeh, M.: Efficacy of inactivated H9N2 avian influenza vaccine against non-highly pathogenic A/Chicken/Iran/ZMT-173/ 1999 infection. Arch Razi Inst 53, 23-26 (2002).

22. Tavakkoli, H., Asasi, K., Mohammadi, A.: Effectiveness of two H9N2 low pathogenic avian influenza conventional inactivated oil emulsion vaccines on H9N2 viral replication and shedding in broiler chickens. Iran J Vet Res 12, 36 (2011). 